\title{
The third party logistics development present situation and restricting factors
}

\author{
Zhang Xiaolei \\ School of Economic and Management \\ Shengyang Aerospace University \\ Shengyang China
}

\begin{abstract}
Third Party Logistics (Third Party Logistics, the TPL or 3PL), It is the 1980's concept in Europe and the United States developed countries, is associated with the concept of modern Logistics theories, outsourcing is a business management concept was introduced into Logistics management area and produce a new Logistics form. Third party logistics is relative to the first party (the shipper or the client) and the second party (the consignee), itself does not have the goods, also do not participate in goods trading, but he is a link between the first party and second party, belong to the intermediate link of logistics, by professional logistics enterprises in the form of the contract within a certain period of time to provide all or part of the services, including transportation, storage, packaging, distribution services and integration of the single links such as integrated logistics services or series multi-function logistics services. This article from the meaning of the third party logistics and the developed countries and China's development situation, analyzed the European and American countries of the third party logistics development situation, and compared with the actual situation in our country, to analyze our country some problems existing in the development of third party logistics, tend to be more international third party logistics development in China.
\end{abstract}

Keywords-The third party logistics; Domestic logistics; Quality of service; Supply and demand; The supply chain

\section{INTRODUCTION}

With the progress of the age, the development of science and the intensifying of global competition, the logistics science became one of many avant-garde sciences. In enterprise strategy, whether to accept outsourcing logistics has become a topic that can not be avoided.

At present, logistics has been elevated to the strategic level of enterprise's core competitiveness; logistics plays a significant role in improving market competitiveness. Most enterprises introduce the concept of modern logistics, third party logistics and modern operation and management model to business management. However, the affect of the state system makes the logistics sector which should be a whole divided into many small pieces, if a company wants to be work on the domestic road transport, sea transport, air transport, etc., it must apply to the superior departments. As each department is separated from each other and can not make a unified deploy, which results in wasting of many resources. Third Party Logistics is a rising form of cooperation between enterprises, it is a mode of operation to achieve mutual benefit and win-win, meanwhile it can bring benefits for both supplier and buyer to achieve winwin.

\section{THE CONCEPT OF THIRD PARTY LOGISTICS}

In the Chinese National Standards (GB/T18354-2001), in the term of logistics, Third Party Logistics is defined like this: business model that supplier provides all or part of the logistics services by parties other than buyer. The logistics services provided by Third Party Logistics can be either several links or integrated logistics services (way of transport, warehouse management, distribution and packaging), or logistics activities of some link (deliver automotive parts to the automotive dealers); Third Party Logistics can be either basic logistics services like transport, warehousing and others, or high-level logistics services like logistics systems design, information systems management (offer comprehensive personalized service from system design, project management to implement from cargo owner's point of view).

\section{THE CURRENT DEVELOPMENT SITUATION OF THIRD PARTY LOGISTICS}

\section{A. The development situation of Third Party Logistics in Europe}

In the seventeenth and eighteenth centuries, Europe had become the most developed regions in navigation; meanwhile various types of transportation vehicles were fully developed. Many well-known Third Party Logistics companies appeared at that time, at the end of the 20th century and before Europe economic integration, Third Party Logistics really started in Europe.

\section{B. The development situation of Third Party Logistics in The United States}

As one of the world's most economically developed regions, the development of logistics industry in The United States will certainly not lag behind. America is the place where the concept of logistics first appeared, and its research, analysis, planning, design on logistics is more advanced than other parts of the world. For Third Party Logistics, the United States has relatively mature logistics management model and modern logistics management experience. In recent years, the Third Party Logistics develops rapidly by 2 digits, the service fields using Third Party Logistics expand. 


\section{The development situation of Third Party Logistics in China}

1) In recent years, the overall increasing speed of logistics industry is slow, in 2013, it will maintain steady and rapid growth.

China as one of the world's major economies, the newtype logistics industry will also be the world's attention. In 2008, Chinese logistics industry suffered a blow by the financial crisis, the industry had some impact. Although it gradually recovers after several years, international financial crisis has also brought some new difficulties; many underlying problems affecting the industry's future development still exist. Overall, China's logistics concept lags behind; the overall quality of logistics industry is low, logistics business operation costs remains high, it can not meet the needs of rapid development of society. The most obvious manifestation is that the total costs of logistics are high for many years, which has obvious gap with developed countries.

2) International logistics enterprises continue to increase investment in China and network expansion speed

With over 10 years since China's accession to the WTO, more and more foreign logistics enterprises come into China. At present, more and more international logistics enterprises establish branches in China, international logistics companies coming to China to develop business is too numerous to mention one by one, they brought a new kind of logistics industry model, which has great impact on China's logistics industry and seriously impact the development of domestic Third Party Logistics.

3) China's logistics industry is "industry situation is complicated", the competition of Third Party Logistics is disperse

Internal contradictions of China's logistics industry are concentrated, competition is dispersed. Currently, the mainstream thinking is that as a newly developing industry, the logistics industry involves multiple categories, customers have communication difficulties with logistics enterprise. Therefore, seen from external, government efforts to manage Third Party Logistics is weak, basically no start.

4) Chinese logistics enterprises start internationalization operation

With the rapid development of China and the fact that the world is optimistic about China, more and more multinational logistics enterprises come into China, pressure of the domestic industry increases sharply. Faced with this competition, taking internationalization route is a good way to withstand. At present, China's large stateowned logistics providers are actively looking for opportunities to cooperate with foreign investment, meanwhile they also increased their overseas business development. More and more local logistics companies go international.

\section{RESTRICTING FACTORS FOR THE DEVELOPMENT OF THIRD PARTY LOGISTICS IN CHINA}

\section{A. The logistics concept lags behind}

According to the fifth nationwide logistics supply and demand situation survey (as shown in Figure 3.1) organized by China Association of Warehouses and Logistics, in China, for enterprises using Third Party Logistics company services among production enterprises, dark gray represents $13 \%$ of the enterprises surveyed, in them, the proportion that the Third Party Logistics participates in the finished product logistics operation is $30 \%$ - 60\%; while light gray represents that in the surveyed companies, for $62 \%$ of enterprises, the proportion that the Third Party Logistics participates is above $60 \%$, for another $25 \%$ of enterprises, the proportion that the Third Party Logistics participates is below 30\%. Compared with the result of the fourth survey, the agency proportion of Third Party Logistics companies has improved greatly, but still less than developed countries.

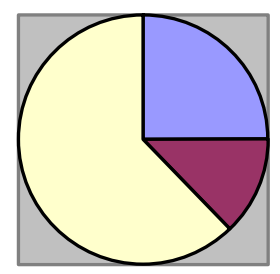

below $30 \%$
above 60

Figure1. The proportion of Third Party Logistics enterprises in all the enterprises

\section{B. The service quality of Third Party Logistics industry} is low

1) The service level of logistics industry is low, work efficiency is poor.

At present, the market share of China's Third Party Logistics is low, resulting in low overall efficiency, and for most Third Party Logistics enterprises, the service item is single, equipment is simple and poor, which can not meet a variety of customer needs. Communication between various enterprises is little; mostly competitor relationship, they can not form a supply chain cooperation partnership of cooperation and joint development. These problems make the producers have doubts about the working ability, facilities quality and service quality of logistics providers, some customers do not trust, resulting in unpleasant cooperation.

2) Low creditworthiness of Third Party Logistics companies

The service basis of all walks of life should be built on the principles of integrity, the logistics industry is no exception. One party hands over the cargo to another party for handling. In the face of Third Party Logistics services or higher level of service outsourcing, not to establish a thorough credit system for support but rely entirely upon intangible trust as basis is impossible. Value-added services provided by Third Party Logistics are mostly invisible.

3) .The working satisfaction of Third Party Logistics is low

Low efficiency and low creditworthiness result in lower satisfaction with Third Party Logistics enterprises. 
Due to the slow development of domestic logistics, Third Party Logistics is congenitally deficient, so domestic Third Party Logistics enterprises are concentrated on some basic logistics with less involvement in logistics valueadded services, which results in lack of logistics service standards and higher level of customer dissatisfaction.

\begin{tabular}{|c|c|c|}
\hline Reasons and factors & $\begin{array}{l}\text { Production } \\
\text { enterprises }\end{array}$ & $\begin{array}{r}\text { Commercial } \\
\text { enterprises }\end{array}$ \\
\hline the operating cost is high & 30 & \\
\hline information is not in time and inaccurate & 23 & \\
\hline operating speed is slow & & \\
\hline service content is incomplete & 21 & \\
\hline rate of damaged cargo is high & 13 & 43 \\
\hline error rate of operating is high & 19 & 29 \\
\hline service attitude is bad & 13 & 25 \\
\hline there is no web service & 11 & 25 \\
\hline can not meet the needs of demand fluctuation & 15 & 3 \\
\hline can not provide supply chain integration & 9 & 8 \\
\hline can not provide management and consultation service & & 6 \\
\hline \multirow[t]{5}{*}{ others } & 12 & 11 \\
\hline & & 7 \\
\hline & 7 & 2 \\
\hline & & 7 \\
\hline & 3 & 17 \\
\hline
\end{tabular}

Figure 2. Proportion of all kinds of reasons causing dissatisfaction with the logistics services in both kinds of enterprises $(\%)$

\section{Unstable supply and demand relation of logistics services}

The supply and demand parties of Third Party Logistics service focus only on current interests, mostly mutually carry out one-off deal or just temporary partnership. They do not appear in the form of cooperation, but the buyer in dealings, they are lack of supply chain mechanism between them. This is the biggest flaw in the development of Third Party Logistics. If long-term cooperative supply relationship is not established, then it will be difficult to achieve remarkable development of the logistics industry.

\section{1) Contain among various Third Party Logistics companies}

The development of domestic Third Party Logistics is very fast, but the opportunities and challenges often coexist, there are difficulties everywhere in the process of development. Some Third Party Logistics companies actively seek cooperation. Through communication and cooperation in many ways, they also have some their own experience. Of course, different logistics providers also have their own advantages and disadvantages. Here's to analyze as shown in Table I

\section{Lack of logistics professionals}

Third Party Logistics develops in an era of rapid development of high and new technology, high-end tools like network informationization, logistics information system emerge one after another, high-end operators are needed to manage these tools, as the development of Third Party Logistics in China is late, this kind of high-end logistics practitioners are still very inadequate, domestic professional and vocational logistics training schools can not keep up with the foreign countries advanced in logistics. Lack of talents, the staff quality working in logistics companies is generally low, which is key factor constraining the development of Third Party Logistics in China. At the same time the administrative staffs of production and management enterprises still lack experience implementing logistics operations. 
TABLE I COMPARE OF ADVANTAGES AND DISADVANTAGES OF ALL KINDS OF THIRD PARTY

LOGISTICS PROVIDERS

\begin{tabular}{|c|c|c|}
\hline $\begin{array}{c}\text { Traditional transportation and } \\
\text { warehousing companies }\end{array}$ & $\begin{array}{l}\text { The new logistics } \\
\text { companies }\end{array}$ & $\begin{array}{c}\text { Internal logistics department of } \\
\text { production and circulation } \\
\text { companies }\end{array}$ \\
\hline $\begin{array}{l}\text { Large state-owned enterprises } \\
\text { have nationwide network and a } \\
\text { number of transportation and } \\
\text { warehousing assets, they have } \\
\text { good relations with central and } \\
\text { local governments. }\end{array}$ & $\begin{array}{l}\text { Seems with joint } \\
\text { ventures, business } \\
\text { areas, services and } \\
\text { customers are relatively } \\
\text { concentrated, efficiency } \\
\text { is relatively high, and } \\
\text { growth is fast. }\end{array}$ & $\begin{array}{l}\text { Primarily service internal } \\
\text { customers, with speciality, assets is } \\
\text { limited, network coverage is good. }\end{array}$ \\
\hline $\begin{array}{l}\text { The proportion of redundant } \\
\text { staff is high, inefficient, focusing } \\
\text { on internal corporate culture and } \\
\text { rather than customer and } \\
\text { performance oriented. }\end{array}$ & $\begin{array}{l}\text { Only has limited fixed } \\
\text { assets, lack strong } \\
\text { financial support for } \\
\text { market expansion, } \\
\text { internal management } \\
\text { and systems are major } \\
\text { obstacles for fast } \\
\text { growing. }\end{array}$ & $\begin{array}{l}\text { Difficult to attract more } \\
\text { external customers, strategy and } \\
\text { future positioning are negatively } \\
\text { impacted by parent company. }\end{array}$ \\
\hline
\end{tabular}

\section{E. Logistics information system lags behind}

\section{1) China's logistics information system lags behind}

As the 21 st century is the era of rapid development of information technology, information is timely, rules and standards are increasingly important. Logistics information resources integration increasingly attaches attention from enterprises, the development of information system exists in every link of the development of Third Party Logistics enterprise. However, the development of China's logistics information system extremely lags behind, which has become the "bottleneck" for the development of China's Third Party Logistics enterprise. The information communication of logistics link is poor, cooperative consciousness between enterprises is not strong, which all constraint the development and growth of Third Party Logistics in China.

2) The level of logistics information standardization in China is low

Logistics standardization refers to taking the standard provided by logistics system as object, establish about warehousing, packaging, processing, distribution and logistics information systems. By publishing related experience and working standards as well as in accordance with the established requirements, integrate and improve the standards of logistics system. It includes information standards, operating standards and program standards. Standardization of logistics information will be the only way which must be passed for future development of China's logistics.
Logistics content includes multiple links like warehousing, in the aspect of services, it involves many industries such as automobile, electronics, food, all kinds of supplies, they are like bonds to be linked to a whole by logistics information systems, because of the lack of basic standards of information in China, different information and different interfaces become a stumbling block to constraint the development of informatization. This will require more work in terms of logistics specialty codes, EDI, etc.

\section{IDEA OF THIRD PARTY LOGISTICS DEVELOPMENT IN CHINA}

It has been 12 years since China's accession to the WTO, in the 12 years, Chinese market has already turned into international market, more and more foreign logistics providers come into domestic logistics market, which brings enormous pressure to domestic logistics companies. So if our Third Party Logistics industry wants to get a place in international competition, we must endeavor to take up measures to promote the development of the logistics industry, changing the present status.

\section{A. Enterprise logistics mode transformation}

Since the birth of the term logistics, the self-run logistics takes up half of the logistics industry, which has great constraint on Third Party Logistics this rising star. How to choose between the two, it depends on perspective and direction of production and operations. In actual operation, choose logistics services according to the 
specific circumstances of enterprises, either gradually outsourcing or all outsourcing.

\section{B. Reputation is the driving force for the development of Third Party Logistics companies}

\section{1) Enhance service awareness}

The purpose that customers seek cooperation with logistics service providers is to enhance service awareness and reduce logistics costs, the major challenge that logistics service providers face is to improve service level. However, as customers are in different industries, there are all kinds of different logistics requirements, so for the industrial characteristics of the target industry, formulate logistics management mode suitable for them.

\section{2) Maintain good reputation}

The basis that customers are willing to outsource business to logistics service providers is the good reputation of the company, if logistics service providers want to work on logistics business, good reputation in the market is the key to get the trust of customers.

3) Attach importance to the training of logistics talents

The society develops rapidly, demand for talents is more and more intense. High-end logistics talents training should be mentioned on the agenda of various aspects, because whether there is talent is the fundamental that whether one enterprise develops. The gap in terms of equipment, technology and capital is the thing what we can see, while as the "invisible hand", talent is more important. Only the knowledge level and professional proficiency of logistics practitioners are improved, China's Third Party Logistics industry can be developed.

4) Strengthen the network construction with the core of information technology application

One of important symbols of modern logistics enterprises is the construction of informationization. The construction of information network can provide multiangle and multi-channel logistics information acquisition mode for logistics services. Through information systems, companies can improve business processes, provide customers with pleasant logistics services, and establish a kind of efficient management and business model. Under conditions of rapid development of the world logistics, the logistics market involves in every corner home and abroad, the development of logistics network is increasingly important.

\section{CONCLUSION}

The development of Third Party Logistics is relatively mature in foreign countries, while the development level of the domestic Third Party Logistics is still relatively low, but domestic demand is growing, the level of demand is also increasing. Having such favorable conditions, the development of our Third Party Logistics will be formidable. Therefore, the paper analyzes the main current problems of Third Party Logistics and the cancer that constrains the development of China's logistics industry fundamentally, provide convenience for the discuss of our Third Party Logistics development. For the problems appear in the course of the operating process of Third Party Logistics companies in China, we must emphasize the importance of Third Party Logistics in the course of business operations, and we should have sense of urgency, attach more importance to the development of China's logistics industry.

\section{REFERENCES}

[1] Tong Qingping Study of development status of Third Party Logistics industry Logistics Technology [J] 2007 Issue 9

[2] Xin Xiafen Problems and solutions in the development of China's Third Party Logistics [J]. Era trade 2008 (96) 118

[3] Ma Pu Discussion of organizational functioning pattern of Third Party Logistics [J]. Mechanical Management and Development, 2009, (01)

[4] China Federation of Logistics and Purchasing. Top 50 ranking of China Logistics Enterprises in 2009 [J]. China Logistics and Purchasing, 2010 (2).

[5] Zhou Qilei. Logistics Generality [M]. Tsinghua University Press, 2008

[6] China Association of Warehouses and Logistics. The sixth Survey of China's logistics market supply and demand [J]. Logistics Technology and Applications, 2005 (11).

[7] Retrospect of development of Third Party Logistics of logistics services industry in 2010 and 2011 outlook [A], Chapter One Logistics Services Industry, China Logistics Development Report

[8] QU LF. Study on the development of agricultural mechanization in China [J].Agricultural Economy, 2010( 8) : $9-11 .($ in Chinese)

[9] YU YK. Current situation and future of agricultural products logistics third- party logistics [ J ] . Logistics Sci - tech, 2010( 8): 7-8.(in Chinese) 